\title{
Building Research Capacity in New Universities During Times of Academic Drift: Lecturers Professional Profiles
}

\author{
Didi Griffioen (10) \\ Amsterdam University of Applied Sciences, Amsterdam, The Netherlands. \\ E-mail: D.M.E.Griffioen@hva.nl
}

New universities on the European mainland were mostly teaching oriented until the start of this century. Current national and local management intends to better connect research and teaching through the increase in lecturers' research capacity, often defined through their master's degrees or PhDs. However, this strategy is complex due to the needed combination of didactical expertise, professional practise, and research competencies in lecturers' professional profiles, which are not captured by the notion of formal degrees. This study considers the professional profiles of new lecturers through a thematic analysis and a correlation analysis of tasks and competencies in job openings $(N=126)$. The findings show that two professional profiles underpin the hiring of new lecturers: the teaching lecturer and the research-active lecturer. These profiles do not imply a better connection between research and teaching. To reach this goal, higher education policy should explicitly define lecturers' professional profiles beyond their formal degrees.

Higher Education Policy (2020) 33, 347-366. https://doi.org/10.1057/s41307-018-0091-y; published online 18 May 2018

Keywords: higher education; professional profile; human resources; institutional policy; research-teaching-nexus; vocational

\section{Introduction}

This article considers new universities' ability to build their research capacity. The European Commission $(2017,5)$ states the importance of research experience for the innovative capacity of talents working in different European countries: The innovations of tomorrow depend on research undertaken today and on creative talent to exploit the results. At the same time, the European Commission $(2017,2)$ considers that some work is to be done on how students are trained to become talented innovators: [...] [R] esearch is not exploited enough as input for teaching, while undergraduates are often not involved in research. This limits students' opportunities to explore contemporary issues and develop their research skills. New universities on the European mainland were mostly teaching-only until the start of this century. A development towards more research activity has since 
occurred, which is also called 'academic drift' (Griffioen and De Jong, 2013; Harwood, 2010). The additional focus on research also implies an increase in research capacity. Building research capacity is defined as a process of individual and institutional development that leads to higher skill levels and greater ability to perform useful research (Grange et al., 2005, 32).

Building research capacity in the new universities on the European mainland is not new, however. During prior decades, similar increases in research capacity have been seen at the system level in the UK where polytechnics became full universities (Neave, 1978). Many examples of building research capacity can be found in disciplinary institutes, where institutes of health (Levine et al., 2013, teacher education (Hill and Haigh, 2011), and engineering education (Brodie et al., 2011; Christensen and Erno-Kjolhede, 2011) moved into the university setting and became more active in research. In many of these settings, the traditional lecturers' work became increasingly academic (Ellis et al., 2012; Hales and Clarke, 2016).

A difference in this study is that in most of these cases, the indented effect of an increase in research capacity was related to an increase in research output, such as research publications or research grants (Levine et al., 2013), combined with a duality of tasks (Ellis et al., 2012). However, the intent of the Dutch hogescholen — the context of this study - was to enlarge their research capacity to improve the quality of education, while research output was of a second order (Ministerie van OC\&W and HBO-raad, 2001, 2004). To reach that aim, national and local strategies have been put in place to raise lecturers' formal educational levels, which is one of the five elements of research capacity (Grange et al., 2005). However, an educational aim related to research in education implies lecturers' didactical competencies, professional competencies, and research competencies. While research competencies are part of the learning goals of master's degrees and $\mathrm{PhDs}$, didactical competencies and professional competencies are not necessarily implied by holding these degrees. This results in more complex professional profiles for lecturers, which then requires more complex strategies, while it is unclear which lecturers' professional profiles are implied in practise.

This article provides the first insight into the professional profiles that underpin the hiring of lecturers in new universities. A better insight into these professional profiles can help guide the dialogue on how to raise research capacity.

\section{Strategies to increase research capacity}

An increase in lecturers' research capacity implies a change in their professional profiles: a change in the working repertoire of the expertise enabling an individual to perform preform professional tasks (Koster et al., 2005, 158). While the concept of an increase in research competences is embraced by policy makers on the international, national, and institutional level, the actual increase in research capacity in lecturers is not easy to manage in practise. Technically, two strategies to 
increase lecturers' research capacity can be distinguished (Levine et al., 2013): to professionalise lecturers into more research competencies or to hire new lecturers with more research competencies. Both strategies have been shown to be complex.

\section{Professionalisation as a strategy}

Lecturers in teaching-intensive settings were traditionally mostly hired for their professional competencies and didactical competencies rather than for their research expertise (Pratt et al., 1999). As an effect of the "holy trinity of academic identity' - research, teaching, and scholarly activity — research is often not part of teachers' professional identities (Feather, 2010). Previous research has shown that attitudinal barriers and organisational barriers are often in the way of bringing research into the identities of lecturers who mainly see themselves as 'good teachers' (Brodie et al., 2011). Furthermore, the development of research competencies alongside the demands of teaching and the active involvement in a professional field has led to an intertwining of social and logistic tensions that are not easy to solve (Hill and Haigh, 2011). Often, lecturers who try to increase their research competencies experience a lack of opportunities, too high of a workload pressure, a lack of resources, and a lack of protected time (Grange et al., 2005; Kljakovic, 2009). Lecturers taking over the teaching load of colleagues who professionalise in research often consider the re-allocation of this time to be unfair, since research competencies are not always considered beneficial for the quality of education (Van Tholy and Griffioen, 2017). The employment of more teachers to reduce the teaching load is then considered a solution, but this is also a costly endeavour (Hill and Haigh, 2011). Even if replacements are realised, previous research has shown that a lack of proper research examples and a lack of research culture can compromise the outcome of such a professionalisation process (Kljakovic, 2009). Thus, even with the Dutch national government subsidising the raising of lecturers' educational levels, it remains a costly, time-consuming, and socially difficult endeavour.

\section{Hiring as a strategy}

However, is hiring new lecturers with research competencies more promising? While it seems rather straightforward to formulate lecturers' research tasks and research competencies, previous research in teacher education in England and Canada has shown how research competencies were included in less than $50 \%$ of all job advertisements (Ellis et al., 2012; Hales and Clarke, 2016). To make matters more complex, new Dutch universities do not aim for the traditional successes of increased research capacity (Levine et al., 2013), such as research output, organisational support for research, or community impacts. The new universities examined in this study claim to first and foremost direct the increase in research competencies of lecturers towards the goal to educate highly skilled professionals, and traditional research outputs are considered less important. This strategy 
requests a functional balance between didactical competencies, professional competencies, and research competencies in lecturers that goes beyond a lecturer's formal educational level. This notion diffuses the selection criteria for hiring new lecturers (Brodie et al., 2011). To complicate matters, the selection is mostly done by lower educational management, while top-level management implements the increase in research capacity as a university change initiative. Generally, these lower educational managers were trained as practitioners in the related vocational fields and, therefore, often lack research competencies and research identities (Griffioen and De Jong, 2017). One can wonder if the hiring practises of these lower educational managers act as bridges or buffers to reaching the provided strategic policy goals (Hales and Clarke, 2016).

The search for a functional balance between the three aforementioned competencies is even more complicated if the hiring manager lacks insight in the latter. The combination of this complexity and the usage of lecturers' formal levels of education as a performance indicator has resulted in perverse practises related to current national policy goals (Pidd, 2005; Van Thiel and Leeuw, 2002), such as hiring highly educated but incompetent lecturers or firing wonderfully competent but formally not sufficiently educated lecturers. These types of effects have caused unfriendly social debates about research competencies among the larger group of lecturers and raised support for lecturers' research competencies in general (Van Tholy and Griffioen, 2017).

While the urgency of teaching tasks can also be an incentive for educational managers to mostly focus on content and didactical skills and less on research competencies (Griffioen and De Jong, 2017), one can wonder if the educational managers' hiring strategies actually result in an increase in research capacity. Yet, these hiring strategies on the lowest organisational level are of the upmost importance for the implementation of the intended change from teaching-only to knowledge-based universities (Balogun and Johnson, 2004).

\section{Higher education lecturers competencies}

It is generally accepted that to be a good lecturer in vocationally oriented higher education requires experience in professional practise and didactical experience and skills, which were recently added to research competency. This section provides an overview of higher education lecturers' competencies based on previous frameworks (see Table 1 for an overview). Competencies and tasks both create a professional profile (Koster et al., 2005) in this study, which makes up the professional profile of the lecturer to be hired. Considering the topic of research in education, frameworks were included that considered higher education lecturers' competencies for teaching, competencies for research, and competencies for integrating research into teaching. 
Didi Griffioen

Table 1 Literature overview of lecturers competencies

\begin{tabular}{|c|c|c|c|}
\hline Themes & Codes applied & Research competencies & Teaching competencies \\
\hline \multirow{5}{*}{$\begin{array}{l}\text { A } \\
\text { Knowledge } \\
\text { and } \\
\text { Intellectual } \\
\text { Abilities }\end{array}$} & Vitae (2010) & Pitt and Mewburn (2016) & $\begin{array}{l}\text { Koster et al. }(2005) \\
\text { Tigelaar } \text { et al. }(2004) \\
\text { Briggs (2005) }\end{array}$ \\
\hline & A1-Content & Knowledge Base & Content knowledge \\
\hline & Knowledge & & \\
\hline & $\begin{array}{l}\text { A2-Cognitive } \\
\text { Abilities }\end{array}$ & $\begin{array}{l}\text { Cognitive Abilities: analysing, } \\
\text { synthesising, critical thinking, } \\
\text { evaluating, problem solving }\end{array}$ & $\begin{array}{l}\text { Evaluator and reflective } \\
\text { teacher (assessment and } \\
\text { evaluation) }\end{array}$ \\
\hline & $\begin{array}{l}\text { A3-Creativity and } \\
\text { Innovation } \\
\text { Abilities }\end{array}$ & $\begin{array}{l}\text { Creativity: inquiring mind, insightful, } \\
\text { innovation, argumentation }\end{array}$ & $\begin{array}{l}\text { Contribute to the } \\
\text { curriculum } \\
\text { Developer of education }\end{array}$ \\
\hline $\mathrm{B}$ & B1-Personal & Personal Qualities: enthusiasm, & \\
\hline Personal & Qualities & perseverance, integrity & \\
\hline Effectiveness & $\begin{array}{l}\text { B2-Self- } \\
\text { Management }\end{array}$ & $\begin{array}{l}\text { Self-Management: time } \\
\text { management, commitment, } \\
\text { prioritisation, responsiveness to } \\
\text { change }\end{array}$ & \\
\hline \multirow{5}{*}{$\begin{array}{l}\text { C } \\
\text { Governance } \\
\text { and } \\
\text { organisation }\end{array}$} & B3-Professional & Professional and Career & \\
\hline & Development & Development & \\
\hline & $\begin{array}{l}\text { C1-Professional } \\
\text { Conduct }\end{array}$ & $\begin{array}{l}\text { Professional Conduct: ethics and } \\
\text { copyrights }\end{array}$ & $\begin{array}{l}\text { Positive attitude and } \\
\text { respect towards students }\end{array}$ \\
\hline & $\begin{array}{l}\text { C2-Management } \\
\text { Competences }\end{array}$ & Research Management & \\
\hline & $\begin{array}{l}\text { C3-Resources } \\
\text { and Finances }\end{array}$ & Finance, Funding and Resources & \\
\hline $\begin{array}{l}\text { D } \\
\text { Engagement, } \\
\text { Influence and }\end{array}$ & $\begin{array}{l}\text { D1-Collaborative } \\
\text { and Collective } \\
\text { Attitude }\end{array}$ & Working with others & $\begin{array}{l}\text { Collaboration with } \\
\text { colleagues }\end{array}$ \\
\hline \multirow[t]{2}{*}{ Impact } & $\begin{array}{l}\text { D2- } \\
\text { Communication } \\
\text { and } \\
\text { Dissemination }\end{array}$ & Communication and Dissemination & Communicative Skills \\
\hline & $\begin{array}{l}\text { D3-Engagement } \\
\text { and Impact (incl. } \\
\text { teaching) }\end{array}$ & Engagement and Impact & $\begin{array}{l}\text { Counsellor for students } \\
\text { (feedback giving, student } \\
\text { centeredness) }\end{array}$ \\
\hline
\end{tabular}

\section{Competencies}

Several frameworks have been developed for the teaching competencies of lecturers in higher education. The study by Koster et al. (2005) resulted in four competencies that the respondents considered necessary: knowing and being able to handle the content of a certain field, being able to communicate to others through presentations or to oneself through reflection, having organisational or managerial competencies, and having pedagogical or didactical competencies. These results were rather similar to the ones found by Briggs (2005) and Tigelaar et al. (2004). 
Hales and Clarke (2016) found the two conceptualisations of personal attributes and knowledge and skills and experience to be part of new teachers' educators' job advertisements in Canada. In a similar Australian study among advertisements for academics, Pitt and Mewburn (2016) applied the Vitae Research Development Framework (RDF; Vitae, 2010), which resulted in four groups: knowledge and intellectual abilities; personal effectiveness; governance and organisation; and engagement, influence, and impact. Each of the domains consists of two or three different groups of competencies. Some conceptual debate has taken place about the relevance of personal characteristics in the professional profile of the lecturer in higher education based on the intangible character of these competencies (Koster et al., 2005; Tigelaar et al., 2004). On the other hand, research in English universities has shown that advertisements for new teacher educators actually posit that personal qualities are significantly important (Ellis et al., 2012). Since this study considers the relevant competencies to be those listed in job advertisements, the conceptual debate is considered less relevant.

\section{Tasks characteristics}

Following the notion of a professional profile, several studies considered the activities of lecturers, which are sometimes described as the tasks (Douglas, 2012; Koster et al., 2005; Visser-Wijnveen et al., 2010), and in other settings as the roles of lecturers (Briggs, 2005; Tigelaar et al., 2004). The difference between tasks and roles seems to be that roles are more holistic and can include several tasks. The roles found were those among other team workers, counsellors, teachers, and researchers, while tasks were, for instance, showing professional development, providing an educational programme, taking part in policy and disciplinary development, organising activities with professionals, selecting professionals, and carrying out research. Visser-Wijnveen et al. (2010) and Douglas (2012) considered the tasks of lecturers, specifically in the perspective of integrating research into teaching. The respondents in research-intensive universities mainly considered the task of research important for lecturers (Koster et al., 2005), which was confirmed by the study by Ellis et al. (2012), who considered research and teaching tasks to be part of new teacher educators' job advertisement.

With a focus on lecturers' tasks and competencies combining to depict a professional profile, the research questions in this study asks, 'How are tasks and competencies combined in professional profiles in new universities?'

\section{Method}

In this study, we follow the method of Pitt and Mewburn (2016), who considered the hiring strategies related to the PhD level of Australian universities based on jobopening texts. In line with the work of these authors, we have applied the Vitae 
RDF (Vitae, 2010) to analyse the requested competences in job applications, but unlike Pitt and Mewburn, the job openings of new universities were analysed. Additionally, we applied the codes to both research and teaching competencies, not just to research competencies as Pitt and Mewburn (2016) did. This means, for example, that the code content knowledge is used for all content knowledge listed in the job openings, not only for research-related content knowledge.

\section{Framework of Dutch job structure}

Dutch Universities of Applied Sciences use a job structure based on national job pay scales ranging from 1 to 16 , with 16 being the most advanced. Teaching and research jobs range from 6 to 16. Scales 6-9 are provided for teaching assistants and research assistants. Jobs with autonomous teaching responsibility range from scale 10 to 13 , while scales 14-16 are mainly provided for (senior) researchers. Traditionally, the career paths of lecturers continue into the more managerial roles (also scales 13-16). The formal research roles are relatively recent in these universities, mostly since 2001. Within each scale are multiple pay levels, which are related to the years of experience gained in a certain role. In general, employees raise one pay level each working year; this raise is related to their annual work appreciation.

\section{Sample}

The Dutch universities of applied sciences provide a collective online environment for job applications (werkenbijhogescholen.nl). On a single day (28 June 2016), all posted job openings related to the primary processes of research and/or teaching were selected and downloaded. This resulted in 126 job openings at 20 universities of applied sciences (1-17 job openings per university; for all characteristics, see Table 2). Since all job openings were posted within the same national shared web structure, all headings were similar in summary, job content, university organisation and department, requested competences, particularities, job conditions, and contact information. The content provided per heading varied widely, was not always related to the heading, and all headings were not always used.

This sample included jobs related to teaching and/or research that ranged across pay scale 6-15. On the highest research level-16-no job opening was found.

\section{Coding and analysis}

Data reduction on the competences requested in the job applications was done through thematic coding using the coding scheme applied by Pitt and Mewburn (2016), which was originally developed by Vitae (2010). For the data reduction of the described tasks, a content analysis based on open coding was applied (Joffe and 
Didi Griffioen

Building Research Capacity in New Universities During Times of Academic Drift

354

Table 2 Description of sample characteristics

\begin{tabular}{lllllll}
\hline & Pay scales & $6-9$ & 10 & 11 & 12 & $13-15$ \\
\hline$N=126$ & $N$ & 7 & 42 & 67 & 6 & 4 \\
& & $\%$ & $\%$ & $\%$ & $\%$ & $\%$ \\
\% of full-time & $10-40$ & 14 & 7 & 4 & - & - \\
& $50-80$ & 43 & 40 & 27 & 17 & 100 \\
Contract & $90-100$ & 43 & 52 & 69 & 83 & - \\
Job focus & Fixed term & 86 & 98 & 97 & 100 & 100 \\
& Education & 86 & 90 & 97 & 83 & 50 \\
& Research & 14 & 7 & 1 & - & 50 \\
Degree requested & Education and research & - & & 1 & 17 & - \\
& Secondary vocational education & 14 & - & - & - & - \\
& Higher vocational education & 71 & 14 & 16 & 33 & - \\
& University education (ba/ma) & 14 & 81 & 78 & 50 & - \\
& PhD & - & 2 & 6 & 17 & 100 \\
\hline
\end{tabular}

Yardley, 2004), resulting in a list of tasks mentioned in the job applications. For all coding, Atlas.ti7 was used.

Secondly, all qualitative codes were quantified based on whether a specific competency was requested (0 [not requested] to 1 [requested]) and whether a specific task was described ( 0 [not described] to 1 [described]) in the job application. The result was a combination of binominal scores per job opening in a data file. This data file was used for a correlation analysis in SPSS23.

This correlation analysis was applied to investigate how different described tasks correlate and how tasks and competencies were related. For the interpretation of significant correlations, we used the following criteria: $r<.30=$ weak correlation, $.30<r<.50=$ moderate correlation, and $r>.50=$ strong correlation. Correlations are considered significant at $p<.05$ (in the findings depict with $*$ ) or at $p<.01$ (in the findings depict with **).

\section{Limitations of methods used}

The choice for studying job application texts provides several limitations to the findings. While these texts provide valuable information on current hiring strategies, they do not provide insights into the professional profiles (tasks and competencies) of the lecturers actually hired. What we do know is that these texts are the base for potential candidates to enter the selection process. Furthermore, job application texts are short by definition. Therefore, it is likely that the employer would have listed more tasks and more competencies when the text could have been longer. However, one can expect that the most important aspects for the job opening were listed and that, therefore, these texts provide the most important information. Finally, the sample in this study is based on all the job openings that were listed on a single day. While the period at the end of the college year always 
provides more job openings than during the year, this selection still is much smaller than the total amount of job openings over a full year. Further research should consider the similarities and differences between the written texts and the actual selected lecturers, as well as differences in the interpretation of these texts between the employer and the candidate. Ideally, future research should consider a more extensive sample to confirm these findings and a longitudinal perspective to provide more insight into the changes in hiring strategies in new universities over time.

\section{Findings}

The aim of this study is to investigate lecturers' tasks and competencies in jobopening texts. First, the tasks found will be reported, including the correlation between tasks. Second, the competencies will be described. Finally, the combined tasks and competencies will result in lecturers' professional profiles.

\section{Correlations between lecturers' tasks}

The findings furthermore show how teaching-related tasks, such as lecturing, supervision, and educational development, are more common in job-opening texts than research-related tasks, such as research, acquisition, or dissemination (see also Figure 1). For an overview of all lecturers' tasks found, see Table 3.

The findings of the correlation analysis show that there are two groups of tasks, which are significantly and negatively correlated (see Figure 2): (a) tasks related to lecturing and (b) tasks related to acquisition and dissemination. Lecturing is shown to have negative correlations with acquisition $(-.459 * *)$ and negative correlations with dissemination $(-.262 * *)$. Lecturing is only positively correlated with educational development $\left(.225^{*}\right)$. Correlations significant at $p<.05$ are depicted with $*$, and correlations at $p<.01$ with $* *$.

Both acquisition $(.374 * *)$ and dissemination $(.189 *)$ are positively correlated with task research and research development. Several tasks are positively related to acquisition, dissemination, research, and research development with correlations between .188 and .367 . Of the tasks depicted on the right side of Figure 2, only network development is not correlated with dissemination. Furthermore, network development is positively correlated with student supervision $\left(.184^{*}\right)$. The task examiner was not correlated with any of the other tasks.

\section{Lecturers' competencies}

Data were found on all 12 competencies in the four themes of the RDF (Pitt and Mewburn, 2016; Vitae, 2010), which will be hereafter described. The findings show how content knowledge, personal qualities, and communication and dissemination 


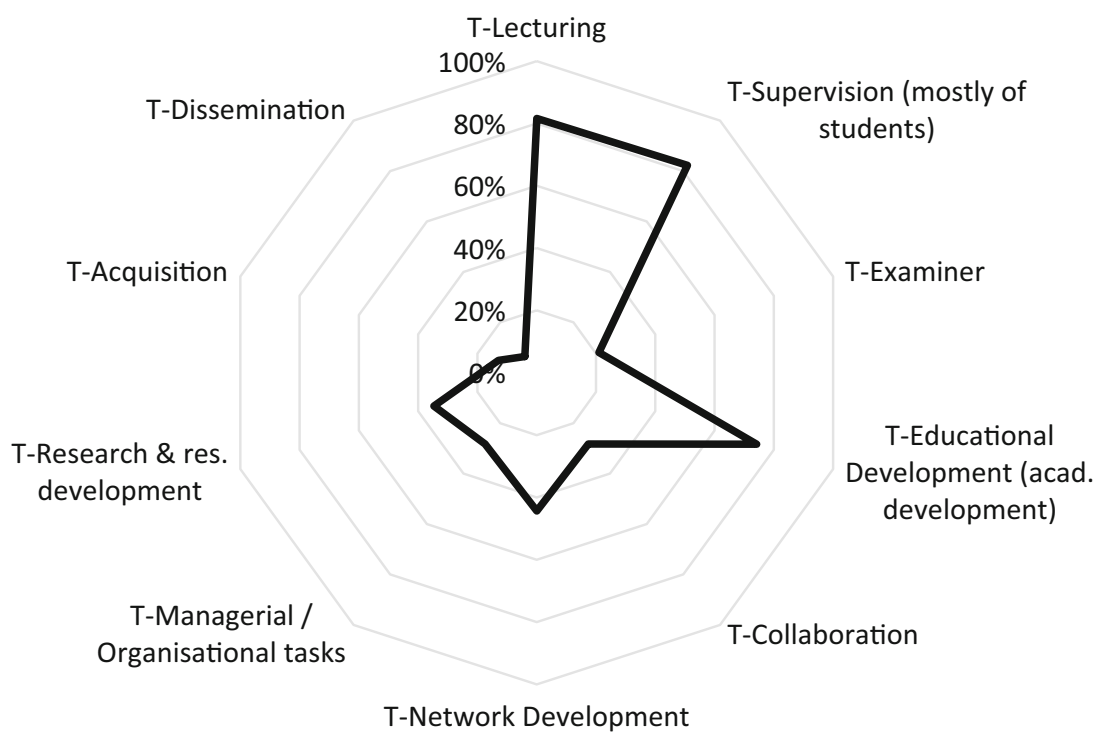

Figure 1. Prominence of tasks in all job openings.

Table 3 Lecturers' tasks as found in job-opening texts

\begin{tabular}{|c|c|}
\hline Lecturing & $\begin{array}{l}\text { Teaching in different formats mostly live, sometimes online, such as } \\
\text { workgroups and plenary classes to full-time and part-time students }\end{array}$ \\
\hline Supervision & $\begin{array}{l}\text { The supervision and coaching of students during their internship or } \\
\text { graduation projects. Sometimes the supervision is explicitly directed to the } \\
\text { personal development of students during their studies. The supervision can } \\
\text { be team-based or individual }\end{array}$ \\
\hline Examination & The measuring and/or assessing of students development and results \\
\hline Educational development & $\begin{array}{l}\text { The further development of educational modules, educational material or } \\
\text { full curricula, also in online programmes }\end{array}$ \\
\hline $\begin{array}{l}\text { Collaboration with } \\
\text { students }\end{array}$ & The work on research projects in close collaboration with students \\
\hline Network development & $\begin{array}{l}\text { Is related to the connection of internal and external partners and the } \\
\text { development of new contacts and networks }\end{array}$ \\
\hline $\begin{array}{l}\text { Managerial and } \\
\text { organisational tasks }\end{array}$ & $\begin{array}{l}\text { The organisation and coordination of aspects of educational programmes, } \\
\text { such as modules or curriculum years, as well as the coordination projects } \\
\text { related to education or research, sometimes in collaboration with the } \\
\text { professional field }\end{array}$ \\
\hline $\begin{array}{l}\text { Research and research } \\
\text { development }\end{array}$ & $\begin{array}{l}\text { Implies the participation in and sometimes the leading of current and new } \\
\text { research projects }\end{array}$ \\
\hline Acquisition & To acquire external research projects \\
\hline Dissemination & $\begin{array}{l}\text { The active spread of knowledge through publication, presentation and } \\
\text { teaching }\end{array}$ \\
\hline
\end{tabular}




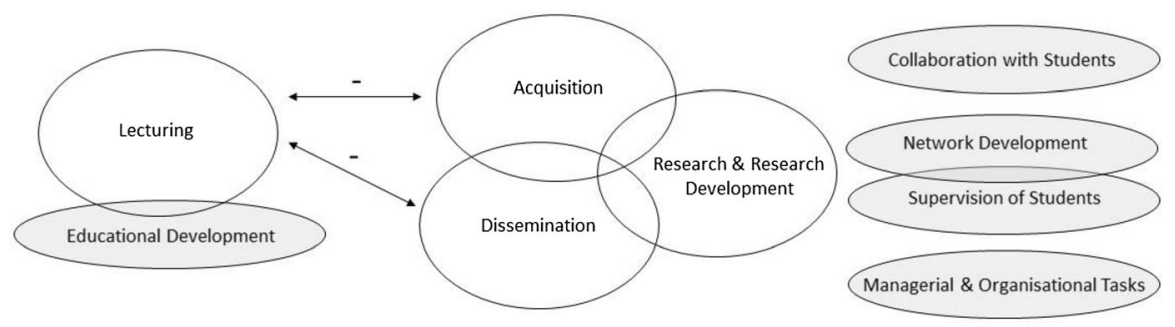

Figure 2. Correlations between job tasks.

are requested in more than $60 \%$ of the job-opening texts. Hereafter, a description of all qualitative findings on competencies will be given per sub-competency (Fig. 3).

\section{Theme A: knowledge and intellectual abilities}

\section{A.1 Content knowledge}

The findings show how almost all job openings describe a certain body of knowledge that a lecturer is expected to be specialist in or has gained experience in. The word 'professionalism' or the phrase 'You have knowledge of and insight into...' are examples mentioning the wish for certain knowledge. Next to the fieldspecific aspects, Dutch and English language proficiency (oral and/or writing) is mentioned in about $20 \%$ of the job openings. Less often, but still present, is the

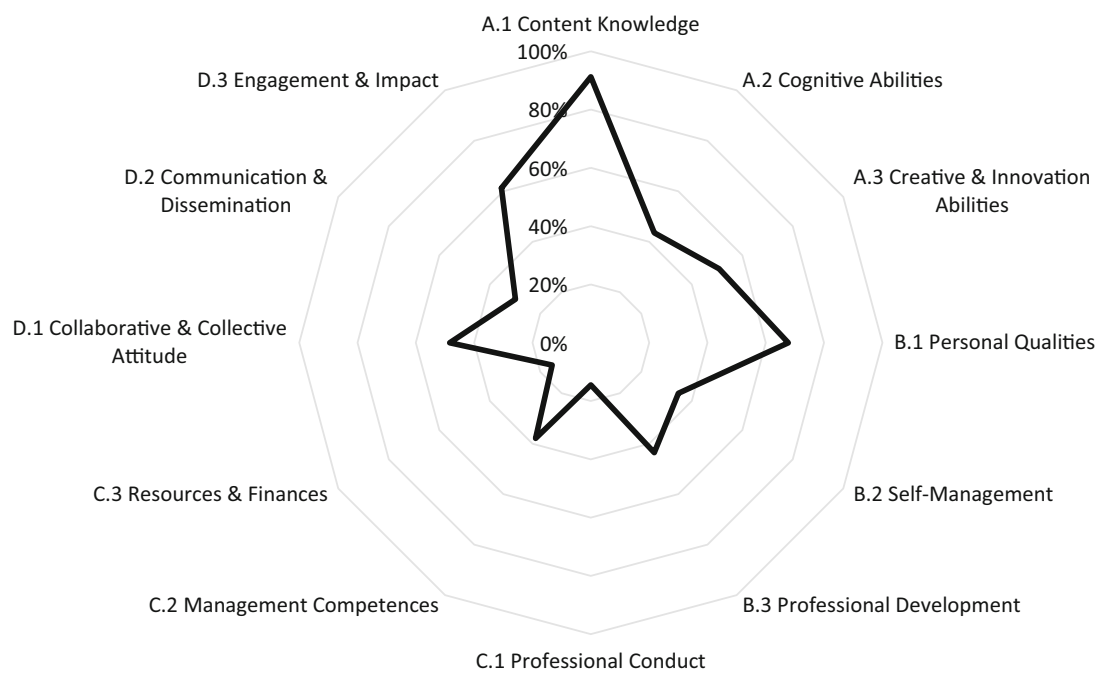

Figure 3. The relative presence of all competencies in the job openings. 
request for educational knowledge, such as about blended learning, e-learning, or flexibility of learning; these are mentioned next to field-specific characteristics and research methods competences. It is mentioned a few times that candidates should be aware of the developments in the field. It is surprising how often field-related competences are formulated in an open way, such as by stating, 'A lecturer should feel affinity with...' or '... should be interested in', instead of the prerequisite of a certain competence, which is stated as 'we expect proven expertise or experience with...'.

\section{A.2 Cognitive abilities}

When requesting cognitive abilities, analytical, synthesis, evaluative, and other abilities are meant. The findings show that cognitive abilities are expected by almost half of the job openings. If they are expected, most request analytical thinking or acting, while a few request critical thinking, the ability to combine or connect information, or a research-oriented ability or attitude. Also mentioned are formulating conclusions, keeping track of the argument, and showing attention to detail. A substantial amount consisted of using the phrases 'research skills', 'inquisitive', or 'analytic abilities' without further explaining their meanings.

\section{A.3 Creative and innovative abilities}

On the subject of creative and innovative abilities, the major competencies that were described in the job opening were being creative and innovative, which included phrases like 'you have a refreshing view on your speciality...' or simply included the use of the words 'innovative' and 'creative'. The second most described aspect of creative and innovative abilities was the ability to combine practical knowledge and to include knowledge from research in education programmes. The most-used ways of phrasing this were 'integrating in your own teaching' and 'transform in motivating lectures'.

\section{Theme B: personal effectiveness}

\section{B.1 Personal qualities}

'Concerning personal qualities, the applicant having a positive attitude' (phrased in several ways) was the most-used preference in this subtheme. The most-used way to describe this was 'enthusiastic', but 'having affinity with...' and 'being passionate about...' were used often. Another often-used preference was being inspiring, motivating, or a related term, 'inspiring', which was the most-used phrasing. Being social was another construct that was often asked for in different ways: 'communicative' and 'team player' are some examples. 


\section{B.2 Self-management skills}

Concerning self-management, being oriented towards results was the most mentioned qualification. In most cases, this was mentioned literally, but sometimes phrasing such as 'You are able to make things happen' was used. Furthermore, selfmanagement skills were often described in terms of independency or responsibility.

\section{B.3 Professional development}

Most phrases on professional development were directed to the possession or willingness to gain a didactic qualification. Other types of professional development often mentioned were 'being eager to learn' and 'reflectiveness' (around onefifth of the openings mentioned these). The most-used phrasing was 'You are able to keep improving based on a reflective attitude'.

\section{Theme C: governance and organisation}

\section{C.1 Professional conduct}

Professional conduct was almost entirely asked for in terms of personal quality orientedness. It was phrased mostly by mentioning 'quality' or by stating that the applicant needed to set high standards regarding quality. Furthermore, quality orientedness as a prerequisite was phrased regarding research, such as to improve it ('to set high demands for the quality of your own work and research').

\section{C.2 Management competencies}

Regarding management competences, the job openings focused on project work or 'project work abilities'. In cases when the job openings were more specific, organisation and planning skills that were wanted were phrased as 'instructing and organizing abilities'. Desired leadership abilities were phased as '...can be in charge, is decisive...'. Also, this phrase was formulated more than once: 'You can work together well in a result-oriented team'.

\section{C.3 Resources and finances}

Two qualifications were aimed at in regards to this aspect of the job opening. One of them is the ability to acquire research projects in terms of experience and knowhow ('You have proven experience with writing research proposals...', 'is skilled to acquire academic and applied research projects'). The other one, though mentioned less, is the applicant having a network that can be used on the job to acquire projects for students.

\section{Theme D: engagement, influence, and impact}

\section{D.1 Collaborative and collective attitude}

The term 'working together' was most often used when referring to collaborative and collective attitudes. Sometimes, the label was simply coined, and other times 
phased as, 'You are able to work together...'. Furthermore, in most of the cases, the term was in the context of ability and less frequently used when discussing the willingness to work together, which labelled people as being a 'team player', being 'team focused', or at a lower frequency, being 'collaborative'. Another way of expressing the wish for collaboration ability was by mentioning the ability or wish to work together in interdisciplinary manners ("...working together with interdisciplinary colleagues'). 'Coaching and development of others...' and stimulating and inspiring others can be counted as distinct categories.

\section{D.2 Communication and dissemination}

'Communication skills' was the most-used phrase when describing this subject, and it was often combined with social skills ('excellent social and communication skills') or in phrases as 'verbal and written communication skills'. The wish for publishing experience was mentioned, but less frequently.

\section{D.3 Engagement and impact}

Engagement and impact were mainly phrased in terms of relevant or recent experience in teaching ('experience in giving lectures...') or in the higher education setting as a whole ('experience in higher education...'). The second most important focus is on didactic skills. This was most often phrased with the words 'didactic', 'coaching', and 'knowledge transfer', which were mentioned by about one-sixth of the job openings. The wish for student-oriented and stimulating applicants ('you can get along with adolescents...') or the affinity with new teaching methods to best serve these students were both related to this. Last, it was mentioned that up-to-date knowledge was requested with the goal to achieve impact in general.

\section{Correlations between tasks and competencies}

To consider the implicit professional profiles in the job openings, the correlations between tasks and competencies were considered. Most tasks were shown to be correlated with only one or two competencies. For an overview of correlations and professional profiles, see Figure 4.

The educational development tasks were shown to be positive correlations with self-management $\left(.251^{* *}\right)$ and professional conduct $\left(.178^{*}\right)$. Already the tasks lecturing and educational development were correlated. Combined, these tasks and competencies result in the 'teaching lecturer' professional profile.

The competency resources and finances were positively correlated with several tasks: research and research development $(.217 *)$, acquisition $\left(.533^{* *}\right)$ and dissemination $\left(.185^{*}\right)$, and network development $\left(.329^{* *}\right)$, while lecturing is shown to have a negative correlation $\left(-.286^{* *}\right)$. Additionally, the task acquisition is also shown to have a positive correlation with communication and dissemination 


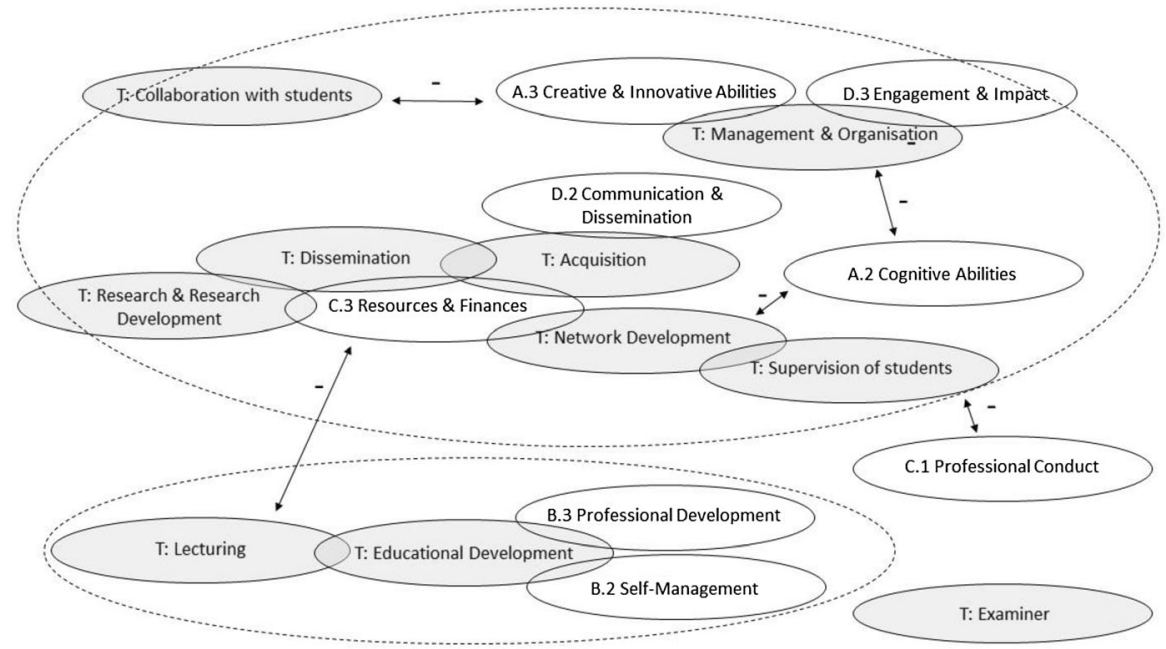

Figure 4. Correlations between described tasks and requested competencies. All overlapping circles depict positive correlation, while the arrows depict negative correlations. Only competencies are included that are significantly correlated with a task.

(.230*). The network development task has a negative correlation with the competency cognitive abilities $\left(-.183^{*}\right)$.

Managerial and organisational tasks have shown a positive correlation with creative and innovative abilities $\left(.198^{*}\right)$ and to engagement and impact (.183*), but a negative correlation with cognitive abilities $\left(-.184^{*}\right)$. The task collaboration with students is negatively correlated with the competency creative and innovative abilities $\left(-.177^{*}\right)$.

Combined, these tasks and competencies result in the 'research-active lecturer' professional profile. Within this professional profile, the sub-profile 'lecturer as research manager' was distinguished. The tasks of this sub-profile correlate with the other research tasks (see Figure 2), but request additional competencies.

Of all the tasks, only the task examiner is not correlated with any of the competencies, and several competencies are not correlated with all tasks. And professional conduct is only negatively correlated to supervision of students $\left(-.225^{*}\right)$. The competencies content knowledge and personal qualities have a high frequency in the job-opening texts (see also Figure 1) and are not significantly correlated to any task, which indicates that they are simply present in most texts and therefore do not results in significant correlations. The three other competencies that do not show significant correlations, professional development, management competencies and collaborative and collective attitude, have less prominence. 
Didi Griffioen

Building Research Capacity in New Universities During Times of Academic Drift

362

The lack of correlation with certain tasks then mainly indicates a lack of clear professional profile.

\section{Conclusion}

This study considered the professional profiles of the job openings in new universities from the perspective of raising the research capacity of these universities though the research competencies of new lecturers. Considering that an increased research capacity is expected to result in a higher-quality education, the connection between research and teaching in the job advertisements becomes relevant.

Based on the findings, the new universities are aiming for two professional profiles for lecturers: teaching lecturers and research-active lecturers, although the research-active lecturers were much less frequently requested. The professional profiles of the teaching lecturers correlate negatively with the research-active lecturers' profile. So while there is no positive or negative correlation between the task of research and research development and the task of lecturing, the findings indicate that teaching lecturers are less often presumed to be active or competent in research-related activities.

\section{Discussion}

While it is extremely difficult to identify how universities conceptualise their employees (Ellis et al., 2012), these findings are in line with the argumentation by Hales and Clarke (2016) that the reality of university employment advertisement does not always conceptualise lecturers in a combination of teaching- and researchbased tasks, or of a combination of teaching- and research-based competencies. So the realisation of the goal to provide more research in teaching settings, which was made by the European Commission (2017) and that has been taken over by many new universities, does not seem applicable in the hiring practices in new Dutch universities - at least, not if it depends on the connection between research and teaching in lecturers' tasks and competencies. This divide is in line with previous research in the English (Hales and Clarke, 2016) and Canadian (Ellis et al., 2012) settings, in which new universities did not completely embrace the task of research for lecturers in teacher education and hence did not provide students the expected educational environment.

In this study, the instrument of job advertising seems to be working as a managerial buffer and not as a bridge in relation to European and university strategy goals (see also Hales and Clarke, 2016). This potentially affects the quality of future higher education. While notions about the connection between research and teaching are generally rather normative (Trowler and Wareham, 2008) and the 
debate of how research and professional knowledge are connected is lively (Young and Muller, 2014), the role of higher education in educating employable professionals is undisputed (Griffioen et al., in review). This role comes with the responsibility of providing students a high-quality educational environment, so they will be educated enough to bring forth the innovations our society needs. Apparently, new Dutch universities are not working as fast towards this environment as they think they are, and this is troublesome.

One can also wonder why job advertisements do not seem to conceptualise the same lecturers as strategic policy. Framed differently, is the buffer provided intentionally? To consider this question, all layers of policy-making are relevant. While future research should provide a more definite answer, previous studies can already provide some insight into the mechanisms within each layer. As explained in the introduction, the lowest layer of educational management that hires new lecturers has a crucial role and that therefore such institutions are not always able or willing to actively select new lecturers based on their research competencies (Griffioen and De Jong, 2015). It has also been shown that in the perspective of changing towards a knowledge institute the influence of lower educational managers on how their lecturers perceive research responsibilities is potentially small, but that they still can combine three strategies to provide change. The first strategy is done by providing decision-making procedures (management policy) to influence lecturers' views on the importance of research, while providing collaborations on educational content (educational policy) and strategies for lecturers' personal development (developmental policy) can positively influence lecturers' research self-efficacy. If the managers themselves become part of changed research perspectives and practises, it is plausible that their hiring strategies will change in the same direction (Boyce, 2003). But future research is needed to investigate these mechanisms in depth and to be able to explain these types of mechanisms.

Not much is known about the influence of university strategy on the lower levels in the organisation, although conceptual work suggests that these incentives can be more stimulating when all are aligned towards the same strategic goal, such as to increase research capacity (Jenkins and Healey, 2005). Hence, future research should show whether quality incentives on the institutional or national level can help stimulate hiring lecturers with research competencies and therefore bring change in the lowest managerial levels in the organisation.

Finally the national policy levels provide its influence. Recent research (Griffioen et al., in review) comparing national strategies shows how the structure and the policy of the higher education system can be more or less directive in defining educational environments, as described by the European Commission (2017). However, while this research considers the potential of three national policy systems, it does not study its effects. Future research should also consider 
the steering influence of national policies on change practises in universities, such as hiring practices.

So, while it is naïve to consider the observed buffer as intentional or accidental, the interaction of all strategic higher education layers in its societal context needs to be taken into account to find strategies with which to build the research capacity in new Dutch universities. Future research needs to provide more directions on how European, national and local policy strategies to improve student learning can result in the requested changes in higher education work-floor practices.

The conclusion of this study is that research and teaching still show a rather clear divide in the hiring strategies of new Dutch universities. For current higher educational practise, a first step to provide more research competencies into teaching practise starts with a clearer definition of what competencies and tasks are requested in new lecturers. By formally only requesting a master's degree or $\mathrm{PhD}$, the strategic educational mangers have left the difficult task of defining a related content to the lowest educational managers. It would be wise if new universities would start a debate about what is requested of a high-quality lecturer in this day and age. This would result in a more holistic definition, including what it means to bring research into teaching (which tasks), as well as what lecturers needs to be able to do (which competencies). This study provides insight into the conceptions of lecturers who are part of the current hiring strategy, and these do not provide the lecturers requested. It is time an active policy debate provides new professional profiles for future higher education lecturers.

\section{References}

Balogun, J. and Johnson, G. (2004) 'Organizational restructuring and middle manager sensemaking', Academy of Management Journal 47(4): 523-549.

Boyce, M.E. (2003) 'Organizational Learning is Essential to Achieving and Sustaining Change in Higher Education', Innovative Higher Education 28(2): 119-136.

Briggs, S. (2005) 'Changing roles and competencies of academics', Active Learning in Higher Education 6(3): 256-268.

Brodie, L., Bullen, F. and Gibbings, P. (2011) Developing an engineering research culture. Paper presented at the IEEE Global Engineering Education Conference; 4 April, Amman, Jordan.

Christensen, S.H. and Erno-Kjolhede, E. (2011) 'Academic drift in danish professional engineering education. Myth or reality? Opportunity or threat?', European Journal of Engineering Education 36(3): 285-299.

Douglas, A.S. (2012) 'Advice from the professors in a university Social Sciences department on the teaching-research nexus', Teaching in Higher Education 18(4): 377-388.

Ellis, V., McNicholl, J. and Pendry, A. (2012) 'Institutional conceptualisations of teacher education as academic work in England', Teaching and Teacher Education 28: 685-693.

European Commission (2017) Communication from the Commission to the European Parliament, the Council, the European Economic and Social Committee and the Committee of the Regions on a renewed EU agenda for higher education. Retrieved from Brussels: http://eur-lex.europa.eu/legalcontent/EN/TXT/?uri=SWD\%3A2017\%3A164\%3AFIN. 
Feather, D. (2010) 'A whisper of academic identity: an HE in FE perspective', Research in PostCompulsory Education 15(2): 189-204.

Grange, A., Herne, S., Casey, A. and Wordsworth, L. (2005) 'Building research capacity', Nursing Management 12(7): 32-37.

Griffioen, D.M.E. and De Jong, U. (2013) 'Academic drift in Dutch non-university higher education evaluated: a staff perspective', Higher Education Policy 26(2): 173-191.

Griffioen, D.M.E. and De Jong, U. (2015) 'implementing research in professional higher education: factors that influence lecturers' perceptions', Educational Management Administration and Leadership 43(4): 626-645.

Griffioen, D.M.E. and De Jong, U. (2017) 'The influence of direct executive managers on lecturers' perceptions on new organizational aims in times of academic drift', International Journal of Leadership in Education 20(4): 451-467.

Griffioen, D.M.E., Ashwin, P., \& Scholkmann, A. (in review). Societal steering mechanisms to ensure employable professionals through higher education.

Hales, A. and Clarke, A. (2016) 'So you want to be a teacher educator? The job advertisement as a construction of teacher education in Canada', Asia-Pacific Journal of Teacher Education 44(4): $320-332$.

Harwood, J. (2010) 'Understanding academic drift: on the institutional dynamics of higher technical and professional education', Minerva 48(4): 413-427.

Hill, M.F. and Haigh, M.A. (2011) 'Creating a culture of research in teaching education: learning research within communities of practice', Studies in Higher Education 37(8): 971-988.

Jenkins, A. and Healey, M. (2005) Institutional strategies to link teaching and research, York: Higher Education Academy. Available on https://www.heacademy.ac.uk/system/files/resources/id585_ institutional_strategies_to_link_teaching_and_research_2.pdf.

Joffe, H. and Yardley, L. (2004) 'Content and thematic analysis', in D. F. Marks and L. Yardley (eds.) Research methods for clinical and health psychology, London: Sage, pp. 56-68.

Kljakovic, M. (2009) 'Developing a teaching research culture for general practice registrars in Australia: a literature review', Asia Pacific Family Medicine 8(6): 1-7.

Koster, B., Brekelmans, M., Korthagen, F. and Wubbels, T. (2005) 'Quality requirements for teacher educators', Teaching and Teacher Education 21(2): 157-176.

Levine, R., Russ-Eft, D., Burling, A., Stephens, J. and Downey, J. (2013) 'Evaluating health services research capacity building programs: implications for health services and human resource development', Evaluation and Program Planning 37(1): 1-11.

Ministerie van OC\&W, and HBO-raad (2001) Convenant Lectoren en Kenniskringen in het hoger beroepsonderwijs, Den Haag: Ministerie van OC\&W, and HBO-raad.

Ministerie van OC\&W, and HBO-raad (2004) Vernieuwd convenant lectoren en Kenniskringen in het hoger beroepsonderwijs, Den Haag: Ministerie van OC\&W, and HBO-raad.

Neave, G. (1978) 'polytechnics: a policy drift?', Studies in Higher Education 3(1): 105-111.

Pidd, M (2005) 'Perversity in public service performance measurement', International Journal of Productivity and Performance Management 54(5/6): 482-493.

Pitt, R. and Mewburn, I. (2016) 'Academic superheroes? A critical analysis of academic job descriptions', Journal of Higher Education Policy and Management 38(1): 88-101.

Pratt, M., Margaritis, D. and Coy, D. (1999) 'Developing a research culture in a university faculty', Journal of Higher Education Policy and Management 21(1): 43-55.

Tigelaar, D.E.H., Dolmans, D.H.J.M., Wolfhagen, I.H.A.P. and Van der Vleuten, C.P.M. (2004) The development and validation of a framework for teaching competencies in higher education, Higher Education, 48, 253-268.

Trowler, P.R. and Wareham, T. (2008). Tribes, territories, research and teaching: enhancing the teaching research nexus, York: Higher Education Academy. Available on https://www.heacademy.ac.uk/resource/ 


\section{Didi Griffioen}

Building Research Capacity in New Universities During Times of Academic Drift

366

tribes-territories-research-and-teaching-enhancing-teaching-research-nexus-literature\#sthash.5NK7FyDy. dpuf

Van Thiel, S. and Leeuw, F.L. (2002) 'The Performance Paradox in the Public Sector', Public Performance and Management Review 25(3): 267-281.

Van Tholy, R. and Griffioen, D.M.E. (2017) 'Professionaliseringswensen op onderzoek van docenten in het hbo', Tijdschrift voor Hoger Onderwijs (2): 55-69.

Visser-Wijnveen, G.J., Van Driel, J.H., Van der Rijst, R.M., Verloop, N. and Visser, A. (2010) The ideal research-teaching nexus in the eyes of academics: building profiles', Higher Education Research and Development 29(2): 195-210.

Vitae (2010) Researcher development framework, Cambridge: Vitae. Retrieved from Cambridge: https://www. vitae.ac.uk/researchers-professional-development/about-the-vitae-researcher-development-framework

Young, M. and Muller, J. (2014) Knowledge, expertise, and the professions, London: Routledge. 